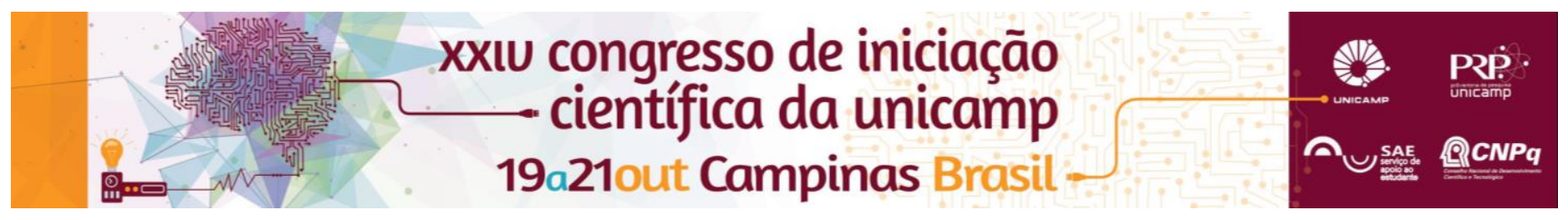

\title{
Efeitos do Ômega-3 na Remissão do Processo Inflamatório Pulmonar em Animais Obesos.
}

\section{Mariana Bessi Pereira}

\section{Resumo}

O presente trabalho buscou avaliar o possível papel anti-inflamatório dos ácidos graxos w3 no pulmão de animais obesos induzidos por dieta rica em gordura saturada. Além disso, analisou-se o conteúdo proteico dos receptores de ácidos graxos insaturados GPR120 e 40 no pulmão de animais magros e obesos.

\section{Palavras-chave: \\ Obesidade, asma, ômega-3.}

\section{Introdução}

Doenças respiratórias como asma, bronquite e doença pulmonar obstrutiva crônica (DPOC) apresentam como característica principal a presença e a propagação de um processo inflamatório crônico. Cada tipo de doença pulmonar possui uma etiopatogênese característica, no entanto, o processo inflamatório de baixo grau disparado pelo acúmulo de massa corporal parece predispor os indivíduos ao surgimento e manifestação das doenças pulmonares, criando um ambiente tecidual propício para o seu desenvolvimento. Nesse ínterim, a incidência de doenças pulmonares de cunho inflamatório se encontra altamente associada à obesidade ${ }^{1}$.

A presença ou a atividade elevada de proteínas inflamatórias como TNF- $\alpha$, IL-1 $\beta$, JNK e TLR-4 no pulmão podem induzir danos teciduais levando à insuficiência respiratória ${ }^{1}$. Diante da ineficiência terapêutica tradicional contra obesidade, nutrientes com funções anti-inflamatórias podem desarticular o processo que precede a instalação de doenças pulmonares associadas à obesidade. Ácidos graxos como o alfalinolênico, apresentam ação anti-inflamatório, no entanto, os mecanismos pelos quais tais ácidos exercem suas funções ainda não foram completamente elucidados ${ }^{2}$. Desta forma, o objetivo deste trabalho foi investigar o papel dos ácidos graxos omega-3 $(\omega 3)$ na inibição do processo inflamatório pulmonar induzido pela obesidade, através de seus receptores GPR120 e GPR40.

\section{Resultados e Discussão}

Ao final de período experimental, os animais do grupo $\mathrm{OB}+\omega 3$ não apresentaram diferença na massa corporal quando comparados aos animais do grupo $\mathrm{OB}$. Entretanto, o grupo $\mathrm{OB}+\omega 3$ apresentou melhora na sensibilidade à glicose após o GTT quando comparado ao grupo OB (Figura-1). Em seguida, deu-se início as análises moleculares para maior compreensão sobre o papel do $\omega 3$ na propagação do processo inflamatório. Nesse sentido, avaliou-se o conteúdo proteico das citocinas TNF- $\alpha$ e IL-10. Os animais do grupo OB apresentaram aumento no conteúdo proteico de TNF- $\alpha$ quando comparados aos animais do grupo CT. Entretanto, os animais expostos a dieta rica em $\omega 3$ não apresentaram redução no conteúdo de TNF- $\alpha$ quando comparados aos animais obesos (Figura 2). Além disso, não verificou-se diferença na quantidade proteica de IL10 entre os diferentes grupos experimentais (Figura 3). Em seguida, o conteúdo proteico dos receptores de ácidos graxos insaturados GPR120 e 40 foram analisados. Os animais dos grupos $\mathrm{OB}$ e $\mathrm{OB}+\omega 3$ não apresentam diferença no conteúdo proteico dos receptors GPR120 e 40 quando comparados aos animais do grupo CT (Figura 2 e 4). Figura 1. Ingestão alimentar, massa corporal e homeostase da glicose
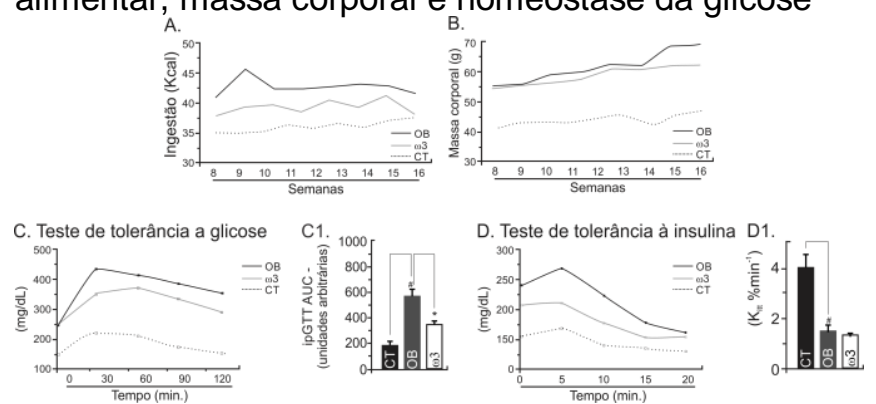

Figura 2. Conteúdo proteico de GPR120 e TNF- $\alpha$

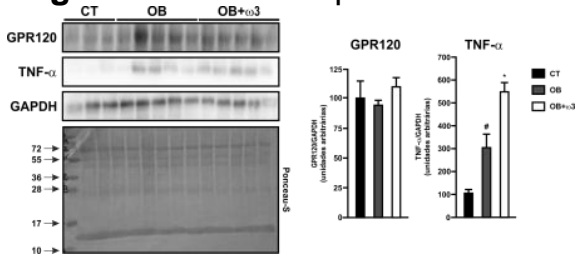

Figura 3. Conteúdo proteico de IL-10

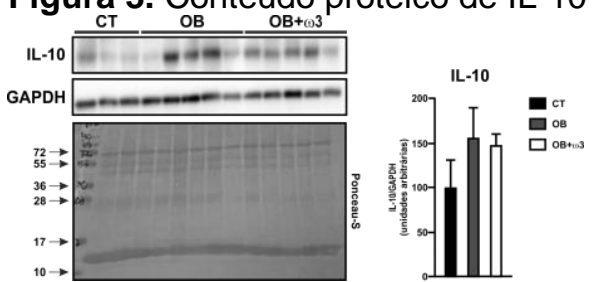

Figura 4. Conteúdo proteico de GPR40

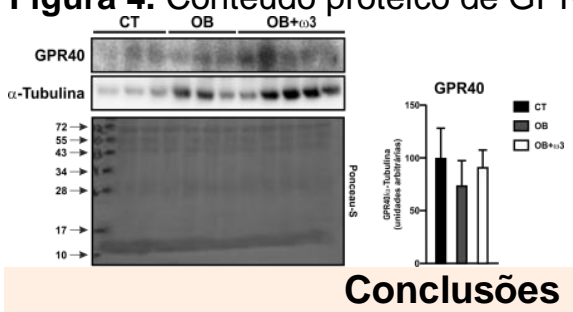

Os resultados obtidos mostraram que a dieta rica em ômega-3 foi de capaz de melhorar à sensibilidade a glicose. Entretanto, nenhuma diferença foi encontrada no conteúdo proteico dos marcadores inflamatórios e dos receptores GPR120 e 40.

\section{Agradecimentos}

Ao professor Dennys Esper Cintra e ao aluno Guilherme Pedron Formigari.

${ }^{1}$ Leiria, L. O. S; Martins, M. A. Saad, M. J. Metabolism. 2015. 64(2):172-81. ${ }^{2}$ Oh., et al. Cell. 2010. 142(5):687-98. 